\title{
THE IMPLEMENTATION OF CDIO STANDARDS \\ IN THE CONTEXT OF 'TUNING' APPROACH WHEN TRAINING TEACHERS OF FOREIGN LANGUAGES
}

Marina G. Golubeva, Nadezhda A. Emelianova, Irina R. Tuigunova, Olga G. Egorova, Uliana A. Saveleva

Astrakhan State University, Astrakhan, Russian Federation

E-Mail: espere402@gmail.com

\begin{abstract}
This article presents the experience of the CDIO (Conceive - Design Implement - Operate) educational standards implementation in the context of TUNING approach: on-going reform of the higher education; introduction of the new generation of Federal State Educational standards (FSES); development of new professional standards. It analyses the results of CDIO implementation monitoring in the system of higher education of foreign language teachers based on the experience gained during the TUNING Russia Project (2010-2019). This article provides an overview of the profiling of TUNING development methodology successfully adapted and applied for the training course for the teaching staff of the foreign languages faculties. Professional competence of a teacher can be shown in a teacher's portfolio, that is a kind of reflection of his/her professional activity and competitiveness which leads to self-assessment and self-development.
\end{abstract}

Key words: TUNING approach, CDIO standards, professional self-development and self-assessment, communicative competence

\section{INTRODUCTION}

Nowadays many universities are implementing CDIO principles (CDIO is a trademarked initialism for Conceive - Design - Implement - Operate) and standards. CDIO is a worldwide initiative (www.cdio.org) and the twelve CDIO standards include:

1 - CDIO as a context (program philosophy) for engineering education

2 - CDIO Syllabus outcomes (learning outcomes for graduating engineers)

3 - Integrated curriculum, designed with mutually supporting subjects

4 - Introduction to Engineering

5 - Design-build experiences (basic and advanced level)

6 - CDIO workspace to support hands-on learning

7 - Integrated learning experiences to acquire disciplinary knowledge, personal, interpersonal, product and system building skills

8 - Active learning, based on active experiential learning methods

9 - Enhancement of faculty CDIO skills

10 - Enhancement of faculty teaching skills

11 - CDIO skills assessment

12 - CDIO program evaluation.

Submitted October $2^{\text {nd }}, 2019$, accepted for publication November $3^{\text {rd }}, 2019$ 
These standards are apparent for every high ranking university and the outcome of an educational program includes personal achievements: critical thinking, creativity, ability to set and solve the problem, team working, leadership, taking responsibility. An educational program must be integrated, i.e. all disciplines are interconnected. It will contain some real situations, and every year the students are to make projects and solve first simple problems, but then the problems will be more difficult and complicated, so the students must be able to deal with them both individually and in teams.

The CDIO standards make it easier to implement new educational standards which acclaim the outcome based approach, but there are no mechanisms to shape competences. Thanks to CDIO teaching does not mean giving students information, it implies practical thinking. Each member of the faculty must understand why he/she empowers students with knowledge, how and where they will apply it.

The CDIO standards are good not only for engineering education, but for teaching humanities as well. Learning foreign languages, for example, is important for making multidisciplinary projects since it helps to analyze, compare, criticize information, do the benchmarking. This can be illustrated with the following likely situation: a student doing research in humanities has to apply sociology, psychology, philosophy, IT design and a foreign language to make it successful. This multidisciplinary approach is realized in an integrated curriculum.

Many universities in different countries are redesigning their syllabi using new academic and professional profiles that incorporate a number of competences. CDIO standards help to reconsider the syllabi and curriculum, improve the quality of education and be more competitive on the educational market.

\section{IMPLEMENTING CDIO STANDARdS IN THE CONTEXT OF TUNING APPROACH BASED ON THE EXPERIENCE GAINED DURING THE TUNING RUSSIA PROJECT (2010-2019)}

The TUNING Center at Astrakhan State University is a case-study. It provides consultative and methodical support in the sphere of TUNING methodology using educational programs development (including a double degree program with foreign educational establishments) for all engaged higher educational establishments and other organizations. The TUNING center was organized in 2010 on the basis of the Educationalmethodological department and it is a structural division of the Federal State Budget Educational Establishment of the Higher Education "Astrakhan State University" (ASU), it is organized by the Rector's order and is subordinated to the head of the International Cooperation project Office. In its activity the TUNING center is governed by the present legislation of the Russian Federation of the Astrakhan Region, by the Rector's orders and arrangements, organization charter, labour contract, rules of internal regulations and other ASU internal local documents.

According to the general regulations the tasks of TUNING-compatible program profiles are the following:

- Contribution to the promotion and distribution of the aims and tasks of the Bologna Process and to the implementation of the integration mechanisms into the Russian educational system.

- Consolidation of the developments, projects and decisions, carried out in the leading higher educational establishments of the region at the basis of TUNING with future organization of the mutual technology and methodic exchange. 
- Providing the consultative and methodical support in the sphere of the TUNING methodology using at the educational programs elaboration (including "double diploma" programs with foreign educational establishments).

- Succeeding in harmonic correspondence of the educational results, set of student competences, curriculum module structure, educational technologies, evaluative means-graduate qualification, fixed by the tutoring community and confirmed by the potential employees.

- Contributing to all engaged higher educational establishments-partners approaching the international educational market.

The main functions of TUNING - compatible program profiles include:

- Contribution to the effective modernization of the regional professional education system.

- Providing facilities for the successful technologies and methodic exchange between regional professional education establishments, transmission of the best modernization experience between educational establishments of all levels.

- Incorporation of the intensions of all participants of the education modernization process in Russian Federation for obtaining the high results of the process.

- Carrying out consultations and education of the partners staff and tutors according to the TUNING and Bologna process methodology, forming of the working skills in the international professional teams.

Material and technical resources must contribute to implementing CDIO standards in the context of TUNING approach - students must have auditoria and room to work in teams and to do a number of practical exercises. Such methods of teaching as interaction, active learning, case studies, excursions, role plays, working in prototype labs, help students understand that each discipline will be useful in their profession. Finally, faculty must be practically oriented and enhance their professional competence according with the 12 CDIO standards.

The term "professional competence" has been used in scientific literature since 1990s, but the notion itself is a subject of special and comprehensive studies by many scholars dealing with pedagogy. Professional competence is understood as a set of professional and personal characteristics necessary for successful teaching. To develop professional competence is to develop self-creativity, to be flexible to innovations and to considerable changes in a teaching/learning environment (Anugerahwati, 2010).

There are several stages of shaping a professional competence: introspection and awareness of necessity, self-development (aims, objectives, methods), self-manifestation, analysis and self-correction. This process is cyclic, since pedagogy requires constant enhancement of professional skills. The stages mentioned above are regularly repeated but with a new way of thinking. Generally speaking, self-development is biologically conditioned and is connected with personal socialization and individualization (Aspin \& Chapman, 2001), which streamlines a person's life and development. Shaping a professional competence depends on teaching/learning environment, which is why it is the environment that stimulates professional self-development. Adhering to the overall ideas of the competence-based approach, we understand under the social competence of students of foreign language faculty the willingness to interact effectively with other persons with the aim of solving professional problems. 
Social competence is directly connected with oral communication and with communication in a foreign language when people of international origins interact. It also comes into play in teamwork, in conflict management and negotiation, and leadership. Interaction is positive through empathetic listening and through clear, assertive expression of what one thinks and/or feels, by verbal and non-verbal means. Mastery of this competence is closely related to orientation towards others, support for others, self-esteem, respect, communication/information, competence/confidence, empathy, personal development, support, etc.

Furthermore, it is a competence that plays an important role in the values involved in personal and social development, such as motivation, self-confidence and self-esteem, the qualities that good intercommunication helps to develop. Moreover, they help to develop orientation toward others and enhance one's capacity to consider and respect others' opinions. So we can consider ASU to be an ideal setting for interpersonal communication because during their years at the university our students can be prepared to develop their capacity to interact with others in different registers: their relations with peers in daily studies and learning; their relations with lecturers; long-lasting or very influential relationships with other university students.

University is also the setting that prepares students for a career in the professional world, where interaction is essential to generate communication between people. Just a few of the situations where interaction with others plays an important role are knowledge transfer, relations at work, job motivation and participation. This competence can be taught through case studies and problem-solving. In order to incorporate it into the academic curriculum it is necessary to generate situations between students that require interaction and cooperation between them, either through joint preparation of cases, or through activities that call for interaction between people and groups. That is why we can define the following levels of mastering this competence: fostering sincere empathetic communication aimed at constructive dialogue; using dialogue and understanding to collaborate and generate relations; establishing good dialogue with peers and professors, listening and speaking clearly and assertively.

\section{Training Course for Teaching StafF of the DePARtMENT OF Foreign LANGUAGES IN COMPLIANCE WITH CDIO STANDARDS}

The academic mobility in Russia is relatively highly developed; teachers and students regularly participate in the international projects and programs of academic mobility, including Erasmus+ programs. Significant methodological results of academic mobility of a teacher are made out in the form of reports and extended or represented at some meetings of scientific and methodological councils of university, faculties and chairs. The recognition of the academic mobility is organized according to the principles declared in the project where a participant is involved in the case that does not contradict the laws of the Russian Federation and the internal charter of higher school.

Such social developments in the modern world and the process of globalization determine the necessity in learning foreign languages. The need for career promotion and the use of innovative technologies in the professional activity of a specialist add to the importance of foreign languages as means of interaction with representatives of other cultures. Implementing efficient programs of learning foreign languages is of great 
importance in the system of lifelong education. It is evident that to implement high standards of education the teaching staff should be trained in a special way as to meet the requirements of the CDIO initiative. This part of the paper presents the program of developing professional competences of teachers of departments of foreign languages. Any teacher has to face a lot of challenges connected with the cooperative forms of communication, thus performing some specific functions: organizing personalitycentered interaction, being the leader and a member of a learning group, having definite authority; being the paragon of moral and ethical behavior; performing as a model interlocutor to students. That is why so much attention is given to the artistic skills of the pedagogue, which means to express creativity in formulating tasks, to use verbal and non-verbal means of communication promptly and efficiently.

An educator often faces challenges connected with interaction with students. To enhance efficiency of the process of learning a foreign language and to overcome difficulties it is vitally important to take account of age and individual psychological differences of students. Taking into consideration age differences are becoming more and more actual nowadays since there are no age limits for going to a college or any kind of training courses. The interest in learning foreign languages never lessens in Russia. There are also students belonging to various ethnic or religious groups in class. So the teacher needs to possess multiple intelligence, including cultural intellect (competence). Knowledge of gender, age, and personal differences are necessary for organizing and activation of the process of education. A competent teacher is able to create favorable atmosphere in classroom, the value of which cannot be overestimated. Our research allowed us to implement a training course in professional competences for teachers of foreign languages. The total of 23 teachers from higher and secondary educational establishments took part in the program.

We suppose that communication competence is most important in a language-learning class to optimize the process of education. This helps make lessons interesting and attractive for older students. The Program includes 3 core components (see Table 1).

Table 1 Core Components of the Program of Training Teachers in the Context of CDIO

\begin{tabular}{|l|l|l|}
\hline Component & Aim & Content \\
\hline Theory & $\begin{array}{l}\text { to introduce some basic theoretical and } \\
\text { practical aspects of professional } \\
\text { competences }\end{array}$ & $\begin{array}{l}\text { Lecture } \\
\text { Practical classes } \\
\text { Outcome-oriented discussion }\end{array}$ \\
\hline Diagnostics & $\begin{array}{l}\text { to introduce methods of research and } \\
\text { estimation of the competences; } \\
\text { to study the level of one's own } \\
\text { competence }\end{array}$ & $\begin{array}{l}\text { Diagnostic techniques to study the } \\
\text { spheres of motivation, communication, } \\
\text { and interpersonal relations }\end{array}$ \\
\hline Methodology & $\begin{array}{l}\text { to introduce the methods of increase of } \\
\text { efficiency of interaction; } \\
\text { training exercises improving skills of } \\
\text { constructive interpersonal interaction }\end{array}$ & $\begin{array}{l}\text { Techniques } \\
\text { Exercises } \\
\text { Games } \\
\text { Feedback }\end{array}$ \\
\hline \multicolumn{2}{|l}{} \\
\hline
\end{tabular}


The program under question is based on the following principles:

- We do not evaluate the personality and actions of our students;

- We work for the process of cooperative activity (not for its formal results);

- We long for person-oriented interaction (not for formal communication in class);

- We encourage partnership;

- We involve all participants in the process.

The theory component presupposes studying the principles of selecting and organizing the teaching material: 1) the process of education is based on the personality oriented approach; 2) there is a link between theoretical knowledge and its practical application. The diagnostic component of the Program includes techniques of studying professional competences in class. The participants are to apply the introduced techniques to their own personality. The analysis of the results allowed them to understand the nature of the difficulties in interaction with students, to evaluate their own skills and peculiarities.

The Methodology component is based on the works of F. Burnard, D. Dickson, O. Hargie, G.A. Kitaigorodskaya, I.A. Zymnyaya (Hargie \& Dickson,2004). The participants are introduced to the system of exercises aimed at the development of all spheres of personality via communication and cooperation in class. We suppose that language classes should include the improvement of some abilities and competences: ability to build interpersonal relations with other members of the group; communication competence, i.e. ability to interact in academic situation; empathy, i.e. ability to feel the inner world of another person.

The participants are given some communication exercises built according to the principles mentioned above or the principles of psychological trainings. The process of learning a foreign language should include gaming techniques that add to the interest in the contents and the process of learning. A language class is characterized by intensity and the importance of concentrating attention, thus demanding psychological and physical relaxation such as rhythmical and dancing exercises, music breaks, singing and painting, language and relaxation games, eye relaxation techniques, humor, etc.

\section{Results of the InVESTigation of Foreign LANGUAGE PROFiCiEnCy ComPetenCe AMONG TEACHERS AND STUDENTS}

Today it is hardly necessary to emphasize the importance of being able to speak a foreign language. The convergence and creation of a European Higher Education Area is much more than a formal process; it is increasingly obvious that people need to be proficient in several languages to get along in society. Because of rapid changes in employment, academic syllabuses in every field, the capacity to communicate in one or more foreign languages is a very important skill. These new aims and context call for a special approach that will promote the capacity for university students to communicate orally and in writing using one or more non-native languages.

This approach starts with a constructivist view in which university students must consider a possibility of developing this competence to increase their training in their chosen field of study, thereby furthering their language skills. Learning at university is moreover intentional learning, and students must be able to exchange information reliably, read and write without difficulty, including university texts.

However, today's context of change, both in society in general and in the workplace in particular, is bringing about a radical change in social structures and community services, 
with new paradigms, when assessment verifies the level of skill and ease with which students handle daily and academic conversations and texts.

The analysis of the reports and self-analyses of the participants of the Program showed that the Foreign Language course was useful and significant. They could change their attitude to the problem of communication competence in a language class.

During the investigation of Foreign Language Proficiency Competence (understanding and making oneself understood orally and in writing using a language different from one's own) a questionnaire was introduced containing some questions, concerning skills and competences, which could be important for construction of successful career in pedagogical education. Fifty students and 15 teachers took part in this investigation. Mastery of this competence is closely related to oral and written communication, diversity and interculturality, interpersonal communication, orientation toward others, solidarity, etc.

We consider their answers to be very useful for perfection and planning curriculums in pedagogical education for future students, graduates, employers, teachers of universities and students. All the respondents were asked to estimate the importance of skill or competence for work in their professional sphere and the level of achievements of each skill or competence of the curriculum of this course.

There were used the following ratings for each of listed below skills:

1) it is not important/zero level;

2) it is unimportant/low level;

3) it is rather important/significant level;

4) it is very important/high level;

5) the highest level.

The results of students and teachers opinion on the most important skills and competences of the list of 17 are given below, in order to illustrate the complexity of meaningful higher education reforms in the respective field and highlight the importance of integrating $\mathrm{CDIO}$ in the reform process within pedagogical education subject area metaprofile in relation to the two factors distinguished with students' opinion ranking in per cent (see Table 2) and pedagogical education subject area meta-profile in relation to the two factors distinguished with teachers' opinion ranking in per cent (see Table 3).

Modern education has rapid development: constantly improving educational processes and changing qualification requirements for specialists. This increases demands for graduates of higher educational institutions on the part of employers, thus the focus is made on interaction with employers when forming educational content, system development order for training specialists for specific jobs. Professional competence of a teacher can be shown in a teacher's portfolio. It is a kind of reflection of his/her professional activity and competitiveness which leads to self-assessment and self-development. A portfolio motivates a teacher, as it collects and summarizes the outcomes of his/her professional activity.

The basic ratings of a foreign language teacher professional competence include such skills as developing personal and interpersonal communication, which are divided into linguistic, thematic, cognitive social and cultural competences. The predominant teaching model in higher education used to be based on a range of contents contained in a program of studies, which would shape students' learning in terms of knowledge. The indicators that make it possible to evaluate proficiency in foreign language assess how well students can exchange information, understand written and spoken discourse and conversations, produce oral and written discourse, and their proficiency in each situation. 
Communicative competence is not only shaping such personal characteristics as sociability, open-mindedness, but also developing practical skills and being able to manage their learning process. It is important for a foreign language teacher to create the environment that will help students show their individual abilities and creativity to solve communication tasks and manifest their attainments and growth.

Table 2 Comparison of the most important skills and competences distinguished with students' opinion ranking in per cent

\begin{tabular}{|l|c|c|}
\hline Questions, concerning skills and competences & $\begin{array}{c}\text { Importance of skill or } \\
\text { competence for work in } \\
\text { future professional } \\
\text { sphere }\end{array}$ & $\begin{array}{c}\text { Level of } \\
\text { achievement of } \\
\text { each skill or } \\
\text { competence }\end{array}$ \\
\hline $\begin{array}{l}\text { Ability to understand principles of } \\
\text { organization of scientific research, ways of } \\
\text { achievement and construction of scientific } \\
\text { knowledge }\end{array}$ & 47.37 & 61,11 \\
\hline $\begin{array}{l}\text { Ability to spend bibliographic and information } \\
\text { retrieval work with a subsequent use of the data } \\
\text { in the decision of professional problems and } \\
\text { registration of scientific articles, reports, } \\
\text { conclusions and so forth }\end{array}$ & 50.00 & 50.00 \\
\hline $\begin{array}{l}\text { Professionalism, ethics and values: ability to } \\
\text { understand and abide by the ethics and values } \\
\text { of the teaching profession }\end{array}$ & 47.37 & 47,37 \\
\hline $\begin{array}{l}\text { Ability to apply confirmed standard methods } \\
\text { and technologies, allowing to solve diagnostic } \\
\text { and corrective-developing problems }\end{array}$ & 52.63 & 44,44 \\
\hline $\begin{array}{l}\text { Ability to select and manage different psycho- } \\
\text { pedagogical diagnostics of level of } \\
\text { development of informative and motivate- } \\
\text { strong-willed sphere, abilities, character, } \\
\text { temperament, functional conditions, personal } \\
\text { for purpose of harmonization of mental } \\
\text { functioning of each person }\end{array}$ & & \\
\hline $\begin{array}{l}\text { Ability to predict changes and dynamics of } \\
\text { level of development and functioning of } \\
\text { informative and motivate-strong-willed sphere, } \\
\text { abilities of character, temperament, functional } \\
\text { conditions, personal traits in the process of } \\
\text { learning }\end{array}$ & 63.16 & 44,44 \\
\hline
\end{tabular}


Table 3 Comparison of the most important skills and competences distinguished with teachers' opinion ranking in per cent

\begin{tabular}{|c|c|c|}
\hline Questions, concerning skills and competences & $\begin{array}{l}\text { Importance of skill or } \\
\text { competence for work in } \\
\text { future professional } \\
\text { sphere }\end{array}$ & $\begin{array}{l}\text { Level of } \\
\text { achievement of } \\
\text { each skill or } \\
\text { competence }\end{array}$ \\
\hline $\begin{array}{l}\text { Ability to spend bibliographic and information } \\
\text { retrieval work with a subsequent use of the data } \\
\text { in the decision of professional problems and } \\
\text { registration of scientific articles, reports, } \\
\text { conclusions and so forth }\end{array}$ & 50.00 & 50.00 \\
\hline $\begin{array}{l}\text { Ability to identify problems and apply } \\
\text { knowledge to solving day-to-day pedagogical } \\
\text { challenges }\end{array}$ & 42.86 & 42.86 \\
\hline $\begin{array}{l}\text { Professionalism, ethics and values: ability to } \\
\text { understand and abide by the ethics and values } \\
\text { of the teaching profession }\end{array}$ & 42,86 & 42.86 \\
\hline $\begin{array}{l}\text { Ability to understand values of humanistic } \\
\text { values for preservation and development of } \\
\text { modem civilization, to perfection and society } \\
\text { development on principles of humanism, } \\
\text { freedom and democracy }\end{array}$ & 42.86 & 42.86 \\
\hline $\begin{array}{l}\text { Ability to apply culture of scientific thinking, } \\
\text { generalization, analysis and synthesis of the } \\
\text { facts and theoretical positions }\end{array}$ & 42.86 & 42.86 \\
\hline $\begin{array}{l}\text { Ability to apply skills of analysis of activity and } \\
\text { methods of emotional and cognitive regulation } \\
\text { (to optimization) of own activity and a mental } \\
\text { condition }\end{array}$ & 42.86 & 42.86 \\
\hline $\begin{array}{l}\text { Ability to apply professionally profiling use of } \\
\text { modem information technology and the Internet }\end{array}$ & 42.86 & 42.86 \\
\hline $\begin{array}{l}\text { Ability to describe structures of activity of the } \\
\text { professional within the limits of a certain sphere } \\
\text { (a psychological portrait of the professional) }\end{array}$ & 42.86 & 42.86 \\
\hline $\begin{array}{l}\text { Ability to reveal specificity of mental } \\
\text { functioning of a person taking into account } \\
\text { features of age stages, crises of development } \\
\text { and risk factors, its accessories to tender, ethnic, } \\
\text { professional and to other social groups }\end{array}$ & 42.86 & 42.86 \\
\hline
\end{tabular}

One of the tools to improve professional competence is self-assessment or selfevaluation of class performance. It gives an opportunity to shape and develop critical thinking and awareness of problems. 
At the end of each course it is necessary:

- to define the role of a particular class in a course, its connection with previous and next courses,

- to characterize the abilities of a student group,

- to define the objectives and decision-taking tools,

- to budget the time of a course, divide its periods rationally and effectively,

- to determine the main notions, facts, ideas,

- to select the teaching methods to present the essential material,

- to find the best evaluation methods,

- to use working spaces and educational premises effectively,

- to see the facilities in terms of chosen design, type of furniture and equipment used for various team projects (in small groups), during lectures and seminars, in big auditoria and in small classroom/project rooms; to see if you use open space student lounges etc.,

- to explain the reasons of student's active participation,

- to find the ways of maintaining a friendly atmosphere in the classroom,

- to think over unforeseen situations and consider different variants of a course.

- to analyze all the objectives: fulfilled and unfulfilled, to decide when the unfulfilled objectives will be solved.

So we can consider the importance of this competence for academic and professional life while mastering one or more foreign languages enables students to broaden their possibilities of learning and social relations and also provides them with the capacity to undertake a wider range of professional projects.

Language faculty staff are highly qualified specialists, whose experience and achievements in generating a student able to deal with real life situations are hard to overestimate. However, there are many cases where faculty members are also required to exercise professional skills similar to those of an engineer, economist, lawyer, etc. depending on the group he/she teaches, i.e. students need to be taught how to plan, conduct and evaluate a project. Moreover, faculty often has to coach and guide students in terms of professional personal behavior concerning team working, collaboration and communication.

Historically, universities have been unwilling to make any changes. Today's universities, however, realize that changes are inevitable; they need to be able to perform efficient change processes driven by external factors such as the Bologna process. W. Bridges in his book Transitions: Making Sense of Life's Changes writes that "to become something else, you have to stop being what you are now; to start doing things a new way, you have to end the way you are doing them now; and to develop a new attitude or outlook, you have to let go of the old one you have now. Even though it sounds backwards, endings always come first. After that you encounter the neutral zone" (Bridges, 2004). So this requires skills in organizational communication and change management.

Current faculty members need professional skills, such as project management, teamwork, (intercultural) communication, as well as an understanding of the industrial and societal context of their work. In agreement with this conclusion, CDIO standard 9 (Enhancement of faculty CDIO skills) and standard 10 (Enhancement of faculty teaching skills) suggest that actions that enhance faculty competence in personal and interpersonal skills, and product, process and system building skills are essential for implementing a CDIO-based education (Crawley, Malmqvist, Brodeur, \& Östlund, 2007).

In the university context we can create or optimize the use of main types of situations that will enable us to work on and assess this competence in our students. First of all, students, 
dealing with problems or situations, must identify what needs improvement, look for and analyze alternative courses of action, take a well-reasoned decision. Secondly, they work with real and hypothetical situations, case or problems where they must analyze and propose a systematic process of innovation. Finally, it would involve an application of the innovation projected onto a real context and analyses of the results obtained.

Within the context of permanent change characterizing today's postindustrial, knowledge-based society, innovation has become a central value for the survival and development of organizations. Companies and institutions have innovative potential to the extent that they employ creative, innovative professionals and develop processes and structures that harness and incorporate that individual potential, turning it into corporate capital. So development of this increasingly important value will help students gain access to the labour market and adapt to their future jobs in a context of these characteristics. Besides, it will enhance their development of attitudes such as flexibility, open-mindedness and adaptation to the environment, which they will need to adapt actively and responsibly in a social context that shares these same characteristics.

\section{CONCLUSION}

Learning is thought of as a way of knowing, understanding, managing and demonstrating each professional action. Universities are therefore institutions where the creation, transmission and management of knowledge are combined. They are centers where people are taught to think and where they learn how to learn. The students' role is to become more involved and dedicated to their own learning, which must now be less dependent and more autonomous, as they progress from their first to last years in the university, in a context where it is no longer a question of guessing the right answer, but of knowing how one arrives at that answer. If the main movement in the convergence process is the paradigm shift from teacher-centered learning to student-centered learning, and assessment is infused into learning, then assessment processes must become more flexible concerning strategies, techniques to be used, persons involved, time frames.

Current social demands on universities require that they not only prepare students adequately, but that they prepare them for life as good citizens of democratic society. The new factors to which higher education must respond (globalization, the influence of information and computer technologies, knowledge management, the need to promote and manage diversity, among others) are producing a change in the teaching/learning paradigm, shifting the focus from the centre to students and their learning process.

Students studying foreign languages at university should utilize these languages not only to perfect them, but also to learn different subjects in a course and by doing so, they will broaden their possibilities for learning and education. At the first level the work should focus on conversation, essay writing and audiovisual aids that will strengthen use of the foreign language according to relevant European standards (Villa \& Poblete, 2008). Another possibility would be to foster group work and interaction in the foreign language in question. At the second level it is important to consider proficiency to be used and how learning of the subject is to be completed - for example, access to information sources and writing of reports or essays.

In the university contexts we can create or optimize the following types of situation that will enable us to work on and assess foreign language proficiency competence with students: effectively planning, directing, evaluating and monitoring a complex project, 
developing an idea until it is materialized in a service or product. So in the course of professional practice, project-based work is so prevalent that it is considered a logical teaching option for training students for professional careers. Project-based learning is used as a strategy to ensure that learning takes place through action, when students learn by doing, in the process acquiring an appropriate methodology for confronting the problem that are sure to arise in their future professional practice.

The results of monitoring of CDIO implementation in the system of Russian higher education of foreign language teachers based on the experience gained during the TUNING Russian Project are presented as a teaching strategy in which students, organized in groups, undertake projects in order to integrate knowledge and skills from several areas, develop high-level intellectual skills, promote autonomous learning and working, teamwork and self-evaluation. Mastery of this form of work is closely related to systematic thinking, decision-making, planning, objective-based management; creativity, innovation, enterprising spirit and quality orientation; interpersonal communication; teamwork and leadership; attitudes such as ability to work and collaborate with others. This involves taking responsibility for economic resources and for human capital and structure; balancing the quality of service offered and creating a stimulating work environment; contributing to the community in the broadest sense; and all with the ultimate objective of educating students.

Efficient assessment requires giving new importance to tutorial work, well beyond traditional tutorials. Coaching is a new function that can emphasize the work of the lecturer, who assumes a more symmetrical role with that of students than in the traditional teaching. As tutors, lecturers plan their teaching, help students to plan their learning, to find meaning in the subject matter being taught, to reflect on the knowledge, to provide resources for students to incorporate along with others that they find elsewhere. They monitor and support students' learning processes, and finally they assess and guide this process, participate in moderating discussion and debates. Without work in this regard, competences will most likely never be developed or evaluated, and if this is the case, no progress will be made towards convergence as required in creating a European Higher Education Area.

\section{REFERENCES}

Anugerahwati, M. Professional Competence for Teachers of English in Indonesia: A Profile of an Exemplary Teacher. 〈www.academia.edu>

Aspin, D., Chapman, J. "Lifelong learning: concepts, theories and values". London: SCUTREA, July 3-5, 2001. 〈www.leeds.ac.uk/educol/documents/00002564.doc>

Bridges,W. Transitions: Making Sense of Life's Changes. De Capo Press, 2004.

Crawley, E. F., Malmqvist, J., Brodeur, D. R, Östlund, S. "Rethinking Engineering Education", in Developing Professional Competences of - JACET, <www.jacet.org/ jacet50books/07.pdf>

Hargie, O., Dickson, D. Skilled interpersonal communication: Research, theory and practice. London, New York: Routledge, Taylor and Francis Group, 2004.

Self Evaluation for Compliance with the 12 CDIO Standards, library.queensu.ca/ojs/ index.php/PCEEA/.../36101.

Villa, A., Poblete, M. Competence-based learning: A proposal for the assessment of generic competences. University of Deusto, 2008. 